\title{
Article \\ Printing with Natural Dye Extracted from Impatiens glandulifera Royle
}

\author{
Maja Klančnik
}

check for updates

Citation: Klančnik, M. Printing with Natural Dye Extracted from Impatiens glandulifera Royle. Coatings 2021, 11, 445. https://doi.org/10.3390/ coatings11040445

Academic Editor: Philippe Evon

Received: 9 March 2021

Accepted: 9 April 2021

Published: 13 April 2021

Publisher's Note: MDPI stays neutral with regard to jurisdictional claims in published maps and institutional affiliations.

Copyright: (C) 2021 by the author. Licensee MDPI, Basel, Switzerland. This article is an open access article distributed under the terms and conditions of the Creative Commons Attribution (CC BY) license (https:// creativecommons.org/licenses/by/ $4.0 /)$.
Department of Textiles, Graphic Arts and Design, Faculty of Natural Sciences and Engineering, University of Ljubljana, Snežniška 5, SI-1000 Ljubljana, Slovenia; maja.klancnik@ntf.uni-lj.si; Tel.: +386-1-20-03-200

\begin{abstract}
Invasive alien plants that damagingly overgrow native ecosystems can be beneficially used to produce natural dyes. Natural dyes are healthier and more environmentally friendly than synthetic dyes, so their use on textiles and other products that come into contact with humans is desirable. In this study, the possibility of using a natural dye extracted from the purple petals of the invasive plant Impatiens glandulifera Royle (Himalayan balsam) for screen printing on various substrates; woven fabrics and different papers made from virgin fibers, recycled fibers, and from fibers of Japanese knotweed, was investigated. The prints were evaluated by color measurements and fastness properties. With the violet dye extract, purple-brown prints were obtained on papers made from Japanese knotweed, and more brown prints on other substrates. They had excellent rub fastness but faded significantly when exposed to light. The wash fastness of the prints on cotton fabrics was moderate and poor on polyester fabrics, but the prints had good resistance to wet ironing. The addition of acid to the printing paste resulted in a lighter violet color, the addition of alkali caused a drastic color change to green, both additives increased the light fastness of the prints but reduced the fastness on fabrics to wet treatments.
\end{abstract}

Keywords: natural dye; Himalayan balsam; invasive plant; printing; textile; paper

\section{Introduction}

Ecological awareness among the public has led to a renewed investigation of natural dyes derived from plants for dyeing and printing textiles. Natural dyes can be extracted from any part of the plant like roots, leaves, fruits, seeds, petals [1]. They have certain advantages over synthetic dyes such as non-toxicity, medicinal properties (e.g., antibacterial activity), UV protective effects, biodegradability, and natural renewability of the plant source [1,2]. Disadvantages of natural dyes are their low wash and light fastnesses and that they can only achieve limited hues, mainly yellow, reddish, and brown [2,3].

Natural dyes from various plant sources, such as alkanet [4-6], rhubarb [4,5,7], manjistha [6], turmeric [5,8-10], marigold [8], chrysanthemum seed [9], locust bean seed [11], madder, buckthorn, walnut bark [12], red poppy [1], Butea monosperma flower [13], golden dock, cutch [14], pomegranate peel [14,15], nutshell, orange tree leaves, dyer's chamomile [15], and annatto $[6,14,16]$ have already been investigated for textile printing.

The aim of this study was to investigate the possible use of an extract from the flower of Impatiens glandulifera Royle for printing, which as a natural dye, has not previously been studied for textile dyeing or printing.

Impatiens glandulifera Royle (of the Balsaminaceae family), commonly known as Himalayan balsam, originally native to Southern Asia (Himalayas), also known as policeman's helmet because of its hat-shaped flower, is an invasive species that is spreading rapidly across Europe and North America, causing harmful effects on native plant species by competing for space, nutrients, and monopolizing pollinators [17].

Due to the harmful spread of invasive alien plants, their removal from the natural ecosystem should be planned, including finding their new beneficial uses. They can be a 
source for the production of paper [18] or the extraction of natural dyes used for wood coating [19] or textile dyeing and printing. A yellow dye from the rhizome of Japanese knotweed has been successfully used for dyeing plasma-pretreated cellulosic fabrics [20], and natural dyes from the leaves of Japanese knotweed [21] and the petals of Goldenrod [22] for dyeing cationic pretreated cotton fabrics in shades of brown and light yellow. The extract of the rhizome of Japanese knotweed has also been successfully used for screen printing on papers and fabrics, where an interesting phenomenon of darkening of the prints from yellow to orange-brown on exposure to light has been observed [23].

In the present study, an extract of the purple petals of Impatiens glandulifera Royle was used to prepare printing inks for screen printing on fabrics and various papers. Antipruritic, anti-anaphylactic, and anti-nociceptive effects of the flowers have already been reported [24]. The use of the flower extract as a dye for human contact products may be desirable due to its medicinal properties. For printing with the low-substantive natural dye, a pigment printing paste with a binder was used as a simple alternative to today's ecologically unacceptable and mostly toxic metal salt mordants [12,15]. In pigment printing, the molecules of the natural dye are held on the fabric surface in a film of polymeric binder that adheres to the fibers [25].

The ability to print was tested on different substrates, such as cotton and polyester fabrics, two commercial papers; one made from virgin cellulose fibers and the other from recycled cellulose fibers, and two innovative papers made from different contents of the stem fibers of the invasive alien plant Japanese knotweed. The violet extract from the petals of Impatiens glandulifera Royle is a mixture of different types of flavonoids [24], the color of which can be altered by changing the $\mathrm{pH}$. Therefore, the influence of alkali and acid additives in the printing paste on the color change of the ink, prints, and their fastness properties on different substrates was also observed. The quality of prints was determined by color measurements and fastness tests to rubbing, light exposure, and on fabrics as well as to wet ironing and washing.

\section{Materials and Methods}

\subsection{Printing Materials}

The following materials were used for printing:

- cotton fabric, woven in linen (manufacturer: Tekstina Ltd., Ajdovščina, Slovenia) with a surface mass of $122.73 \mathrm{~g} / \mathrm{m}^{2}$, hereinafter referred to as $\mathrm{CO}$;

- polyester fabric, woven in linen (supplier: Luna Ltd., Ljubljana, Slovenia) with a surface mass of $175.99 \mathrm{~g} / \mathrm{m}^{2}$, hereinafter referred to as PES;

- papers made from Japanese knotweed in two grammages; 200 and $240 \mathrm{~g} / \mathrm{m}^{2}$, manufactured by Pulp and Paper Institute (Ljubljana, Slovenia), hereinafter referred to as J.k. 200 and J.k. 240, where J.k. 200 contains about 30\% fibers from the stem of Japanese knotweed and J.k. 240 contains about $40 \%$ fibers from the stem of Japanese knotweed, the remainder being commercial cellulose fibers in a ratio of conifers: deciduous (eucalyptus) 1:1;

- $\quad$ paper made from virgin cellulose fibers with the trade name 'IQ premium' (produced by Mondi Group Ltd., Vienna, Austria), grammage of $200 \mathrm{~g} / \mathrm{m}^{2}$, referred to as Paper 1;

- recycled paper unknown producer, grammage of $200 \mathrm{~g} / \mathrm{m}^{2}$, referred to as Paper 2 .

\subsection{Printing Ink Preparation}

The natural violet dye was prepared by the National Institute of Chemistry (Ljubljana, Slovenia) by extraction from the purple flowers of Impatiens glandulifera Royle with $1 \mathrm{M} \mathrm{HCl}$ in methanol.

For the screen printing inks, the printing paste for pigment printing was prepared according to the following recipe with ingredients from AchitexMinerva Ltd. (Vaiano Cremasco, Italy); $150 \mathrm{~g}$ of a self-crosslinking acrylic binder Binder SECONC, $18 \mathrm{~g}$ of acrylic thickener Clear MCS, and up to $1000 \mathrm{~g}$ of demineralized water. 
The violet dye was added in six different concentrations; $0.5,1,2,3,4$, and $5 \mathrm{~g}$ per $100 \mathrm{~g}$ of the prepared printing paste with $\mathrm{pH}$ 7.43. The violet inks from light to dark shades were obtained. To prepare an alkaline printing paste, $1 \mathrm{~g}$ of $\mathrm{Na}_{2} \mathrm{CO}_{3}$ calc. (Sigma-Aldrich, St. Louis, MO, USA) was added to $100 \mathrm{~g}$ of the prepared printing paste, thus raising the $\mathrm{pH}$ value to 8.99 . To this alkaline paste, $3 \mathrm{~g}$ of the violet dye was then added and a bluish-green printing ink was obtained. To prepare an acidic printing paste, $2 \mathrm{~mL}$ of $\mathrm{CH}_{3} \mathrm{COOH} 60 \%$ (Carl Roth, Karlsruhe, Germany) was added to $100 \mathrm{~g}$ of the originally prepared paste to obtain a $\mathrm{pH}$ of 5.38 , and then $3 \mathrm{~g}$ of a violet dye was mixed into the paste and a lighter violet printing ink was obtained.

\subsection{Printing}

The printing inks were applied to the substrates using the semi-automatic screen printing machine SD 05 (RokuPrint Ltd., Dornstadt, Germany) with the flat printing screen made of polyester fabric with 77 threads $/ \mathrm{cm}$ and a thread diameter of $55 \mu \mathrm{m}$ with three strokes of a squeegee.

The prints were dried at room temperature overnight and then cured at $150{ }^{\circ} \mathrm{C}$ for $5 \mathrm{~min}$.

\subsection{Color Measurements}

Color measurements of the prints were made two weeks after printing using the spectrophotometer Eye-One i1 Pro (X-Rite, Grand Rapids, MI, USA) with 45/0 plane geometry, illuminant $\mathrm{D} 65,10^{\circ}$ standard observer, and measurement aperture of $4.5 \mathrm{~mm}$ diameter. The CIELAB color coordinates: $L^{*}$ (lightness), $a^{*}$ (red-green value), $b^{*}$ (yellowblue value) were measured, an average of three measurements was taken for each sample, and $h_{a b}$ (hue) and $C_{a b}^{*}$ (chroma) were calculated.

\subsection{Fastness Tests}

The abrasion resistance test of the ink layer on printed papers was carried out according to ASTM D 5264 using the digital ink rub tester RT-01 (Labthink Ltd., Neu-Isenburg, Germany) at a rubbing pressure of $2 \mathrm{~kg}$ and at a rubbing frequency of $1.8 \mathrm{~s}^{-1} 500$ times [26]. The transfer of ink from the prints to the white paper (Paper 1) used as a receptor and the inked surface of the prints after rubbing were visually assessed.

The fastness of printed ink on fabrics to dry and wet rubbing was carried out using the electronic Crocmeter rub tester (SDL Atlas, Rock Hill, SC, USA) according to ISO 105-X12: 2016 [27]. The resistance of printing ink on fabrics to wet ironing was tested according to ISO 105-X11: 1994 [28]. The fastness of the prints to domestic and commercial laundering was tested according to ISO 105-C06: 2012- test A1S at $40{ }^{\circ} \mathrm{C}$ for $30 \mathrm{~min}$ in the standard washing machine Launder-O-meter (SDL Atlas, Rock Hill, SC, USA) [29]. The color change of the prints and the staining of the white adjacent fabrics after the tests were visually assessed with the greyscales according to ISO 105-A02 [30] and ISO 105-A03 [31], respectively, with ratings from 1 to 5,5 being the best value.

The fastness of the color of the prints on fabrics and papers was tested according to the standard ISO 105-B02: 2014 to artificial light (Xenon arc fading lamp) in the testing instrument Xenotest Alpha (Atlas, Rancho Cucamonga, CA, USA) under the following conditions: $35^{\circ} \mathrm{C}, 35 \% \mathrm{RH}$, and $72 \mathrm{~h}$, alongside with the standard blue reference scale [32]. After the light fastness test, the color change of the exposed prints was evaluated visually by the blue wool references with ratings from 1 to 8,8 being the best value, and colorimetrically by calculating the overall color difference $\left(\Delta E^{*} a b\right)$ between exposed and non-exposed prints according to the formula CIE 1976 [33].

For the presentation of fastness test results for rubbing, wet ironing, and washing, the prints made with inks containing concentrations of 1,3 , and $5 \mathrm{~g}$ of dye per $100 \mathrm{~g}$ of initial printing paste were selected as representative prints for light, medium and dark shades and for comparison with the prints made with $3 \mathrm{~g}$ of dye per $100 \mathrm{~g}$ of alkaline and acidic printing pastes. All prints were considered for the light fastness results. 


\section{Results and Discussion}

\subsection{Color of Prints}

The extract of the flower of Impatiens glandulifera Royle is a complex mixture of different colorants. The petals contain various types of flavonoids such as flavones, flavanone and flavonol monoglucosides and diglucosides, anthocyanins as well as phenolic acids, coumarins, and quinone pigments [24].

For the violet color of the extract, quinones and various types of flavonoids, among the latter mostly anthocyanins, are responsible. All the colorants are $\mathrm{pH}$-sensitive. However, anthocyanins are the most strongly colored of all the flavonoids, with a predominant influence on the color of the extract. The color of anthocyanins can change from red to blue depending on the $\mathrm{pH}$ value of the surrounding solution [34]. Thus, in the initial printing paste with a $\mathrm{pH}$ of 7.43 , the dye extract was violet, where anthocyanins were predominantly in the form of the quinoidal base (A) and some in the anionic form $\left(\mathrm{A}^{-}\right)[34,35]$. In the alkaline printing paste of $\mathrm{pH}$ of 8.99 , further, deprotonation took place and more anionic quinoidal base $\left(\mathrm{A}^{-}\right)$was formed, consequently the extract became bluish-green. In the acidic printing paste of $\mathrm{pH} 5.38$, the color of the ink was lighter violet, where more colorless carbinol (pseudo-base) and slightly yellow chalcone structures were formed. If the $\mathrm{pH}$ was lowered even further, a more reddish color would appear due to the increased formation of a red flavylium cation $\left(\mathrm{AH}^{+}\right)$of the anthocyanins. However, further increasing the acidity of the printing paste was not practical in our case. The thickening agent used was polyacrylate, which swells due to the repulsive action of its anionic carboxylate groups [25]. The acid causes the carboxylate groups of the thickener to convert to carboxyl groups, so the printing paste loses the high viscosity necessary for screen printing.

The highest concentration of the extract (i.e., $5 \mathrm{~g} / 100 \mathrm{~g}$ ) also reduced the viscosity of the printing paste, which caused printing difficulties, especially on more absorbent cotton fabrics where the edges of the prints were smeared. The extract was slightly acidic and therefore impaired the performance of the acrylate-based thickener.

After immediate printing with the violet-colored printing inks, the prints looked purple, but after a day, when the prints were dry, they were browner. This can be explained by the fact that the final color of the print is also influenced by other flavonoids (derivatives of quercetin, kaempferol, etc.) [24,36], naphthoquinones [36], and tannins [37], which are present in the extract.

The spectrophotometric measurements of the prints from light to dark colors are summarized in Table 1 . Table 2 contains excerpts of photographs of some prints to show the visual color difference between prints with different dye concentrations on different substrates. The color of the prints is influenced by the base color of the substrate, especially at lower dye concentrations (Tables 1 and 2). The spectrophotometric measurements of the base color of these substrates have already been published [23].

Table 1. Color values of prints with different dye concentrations on papers and fabrics.

\begin{tabular}{cccccc}
\hline Substrate & $\boldsymbol{L}^{*}$ & \multicolumn{1}{c}{$\boldsymbol{a}^{*}$} & $\boldsymbol{b}^{*}$ & $\boldsymbol{C}^{*} \boldsymbol{a b}$ & $\boldsymbol{h}_{\boldsymbol{a} \boldsymbol{b}}\left(^{\circ}\right)$ \\
\hline \multicolumn{5}{c}{ Prints of $0.5 \mathrm{~g}$ dye $/ 100 \mathrm{~g}$} \\
\hline Paper 1 & 90.78 & 1.85 & -5.41 & 5.72 & 288.88 \\
Paper 2 & 91.02 & -0.51 & 3.69 & 3.72 & 97.83 \\
J.k. 200 & 82.08 & 2.07 & 14.00 & 14.16 & 81.60 \\
J.k. 240 & 74.42 & 4.53 & 21.35 & 21.83 & 78.01 \\
CO & 87.65 & 1.28 & 6.26 & 6.39 & 78.42 \\
PES & 84.67 & 2.74 & 0.93 & 2.90 & 18.73 \\
\hline
\end{tabular}


Table 1. Cont.

\begin{tabular}{|c|c|c|c|c|c|}
\hline Substrate & $L^{*}$ & $a^{*}$ & $b^{*}$ & $C^{*} a b$ & $h_{a b}\left(^{\circ}\right)$ \\
\hline \multicolumn{6}{|c|}{ Prints of $1 \mathrm{~g}$ dye $/ 100 \mathrm{~g}$} \\
\hline Paper 1 & 88.01 & 1.76 & -2.43 & 3.00 & 305.97 \\
\hline Paper 2 & 90.01 & -0.83 & 4.67 & 4.74 & 100.05 \\
\hline J.k. 200 & 81.20 & 2.36 & 14.58 & 14.77 & 80.82 \\
\hline J.k. 240 & 73.33 & 4.72 & 20.75 & 21.28 & 77.18 \\
\hline $\mathrm{CO}$ & 84.29 & 2.87 & 8.23 & 8.72 & 70.75 \\
\hline PES & 76.12 & 5.73 & 7.22 & 9.22 & 51.58 \\
\hline \multicolumn{6}{|c|}{ Prints of $2 \mathrm{~g}$ dye $/ 100 \mathrm{~g}$} \\
\hline Paper 1 & 84.96 & 2.89 & -0.17 & 2.89 & 356.70 \\
\hline Paper 2 & 88.15 & -0.74 & 5.31 & 5.36 & 97.89 \\
\hline J.k. 200 & 78.80 & 3.42 & 15.10 & 15.48 & 77.24 \\
\hline J.k. 240 & 71.62 & 5.21 & 20.00 & 20.67 & 75.40 \\
\hline $\mathrm{CO}$ & 77.93 & 5.40 & 11.11 & 12.35 & 64.07 \\
\hline PES & 74.47 & 5.64 & 7.59 & 9.46 & 53.41 \\
\hline \multicolumn{6}{|c|}{ Prints of $3 \mathrm{~g}$ dye $/ 100 \mathrm{~g}$} \\
\hline Paper 1 & 82.04 & 3.48 & 2.62 & 4.36 & 36.98 \\
\hline Paper 2 & 86.90 & -0.42 & 6.75 & 6.76 & 93.56 \\
\hline J.k. 200 & 75.15 & 4.78 & 15.31 & 16.04 & 72.66 \\
\hline J.k. 240 & 68.87 & 5.95 & 18.09 & 19.04 & 71.80 \\
\hline $\mathrm{CO}$ & 70.38 & 8.61 & 13.78 & 16.25 & 58.01 \\
\hline PES & 66.12 & 7.15 & 9.54 & 11.92 & 53.14 \\
\hline \multicolumn{6}{|c|}{ Prints of $4 \mathrm{~g}$ dye $/ 100 \mathrm{~g}$} \\
\hline Paper 1 & 79.04 & 2.69 & 1.81 & 3.24 & 33.85 \\
\hline Paper 2 & 85.54 & -0.33 & 5.28 & 5.29 & 93.61 \\
\hline J.k. 200 & 73.33 & 5.26 & 15.40 & 16.28 & 71.13 \\
\hline J.k. 240 & 68.41 & 5.91 & 18.62 & 19.53 & 72.38 \\
\hline $\mathrm{CO}$ & 68.98 & 8.11 & 12.99 & 15.31 & 58.01 \\
\hline PES & 64.13 & 7.06 & 8.97 & 11.42 & 51.79 \\
\hline \multicolumn{6}{|c|}{ Prints of $5 \mathrm{~g}$ dye $/ 100 \mathrm{~g}$} \\
\hline Paper 1 & 77.94 & 4.41 & 1.60 & 4.70 & 19.97 \\
\hline Paper 2 & 84.08 & 0.09 & 6.99 & 6.99 & 89.24 \\
\hline J.k. 200 & 72.69 & 6.02 & 15.58 & 16.70 & 68.86 \\
\hline J.k. 240 & 67.73 & 6.49 & 16.94 & 18.14 & 69.04 \\
\hline $\mathrm{CO}$ & 65.56 & 9.49 & 14.26 & 17.13 & 56.36 \\
\hline PES & 57.62 & 7.28 & 8.33 & 11.06 & 48.87 \\
\hline \multicolumn{6}{|c|}{ Prints of $3 \mathrm{~g}$ dye $/ 100 \mathrm{~g}$ (alkaline) } \\
\hline Paper 1 & 80.54 & -1.84 & 12.23 & 12.36 & 98.54 \\
\hline Paper 2 & 85.24 & -2.47 & 11.22 & 11.49 & 102.40 \\
\hline J.k. 200 & 75.15 & 1.24 & 19.64 & 19.68 & 86.39 \\
\hline J.k. 240 & 66.36 & 2.60 & 22.68 & 22.83 & 83.47 \\
\hline $\mathrm{CO}$ & 73.66 & 0.58 & 17.95 & 17.96 & 88.16 \\
\hline PES & 70.67 & -1.12 & 12.35 & 12.40 & 95.18 \\
\hline \multicolumn{6}{|c|}{ Prints of $3 \mathrm{~g}$ dye $/ 100 \mathrm{~g}$ (acidic) } \\
\hline Paper 1 & 84.99 & 0.66 & -0.17 & 0.68 & 345.28 \\
\hline Paper 2 & 87.23 & -1.86 & 5.50 & 5.80 & 108.73 \\
\hline J.k. 200 & 78.06 & 3.80 & 15.92 & 16.36 & 76.57 \\
\hline J.k. 240 & 71.84 & 5.71 & 20.56 & 21.34 & 74.48 \\
\hline $\mathrm{CO}$ & 75.30 & 6.36 & 11.65 & 13.27 & 61.39 \\
\hline PES & 74.75 & 6.43 & 7.06 & 9.55 & 47.66 \\
\hline
\end{tabular}


Table 2. Photographs of substrates and prints.

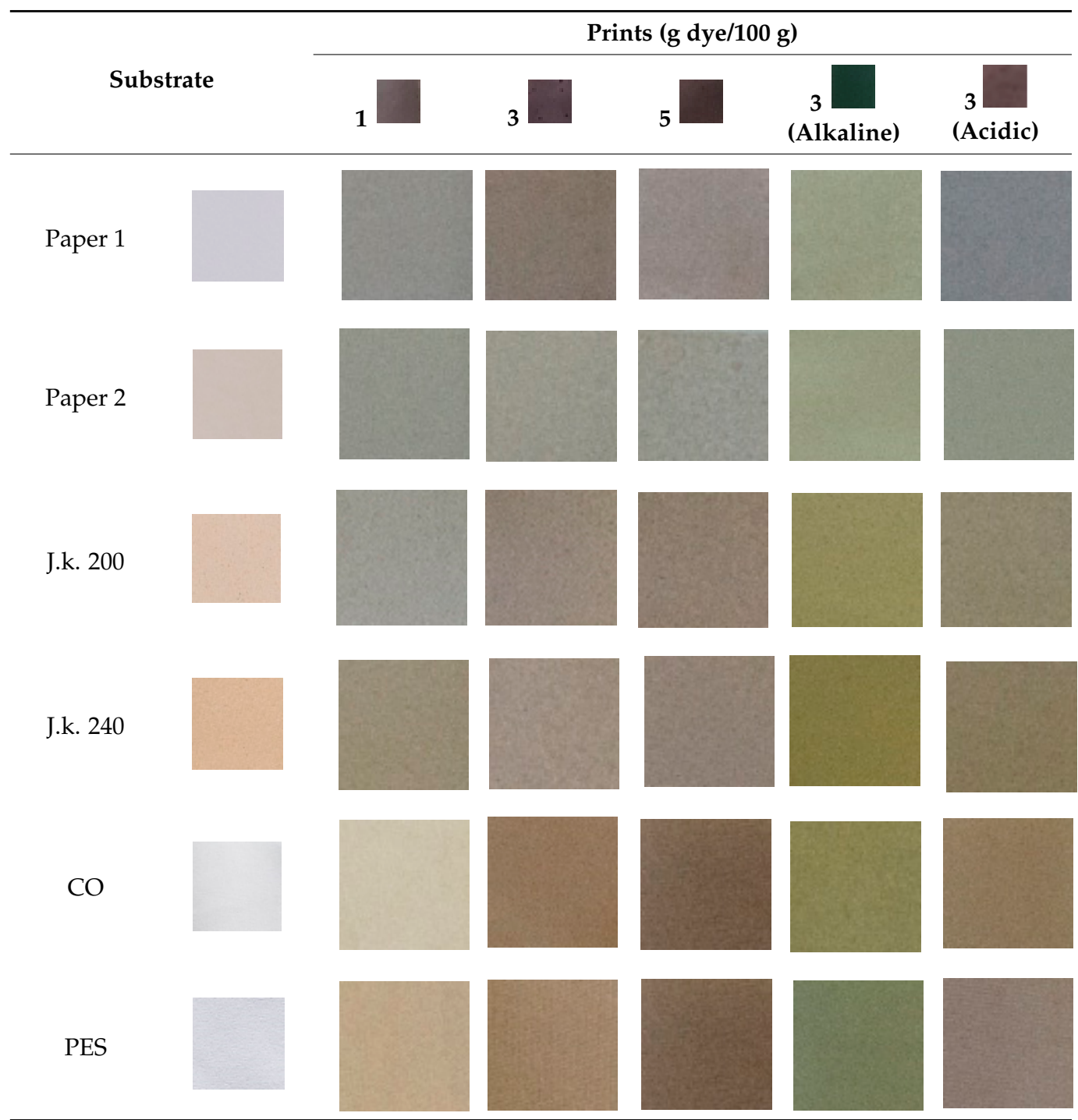

The paper made from virgin fibers (Paper 1) was the whitest of all printing materials, with a violet-blue hue. The prints on Paper 1 obtained with the lower dye concentrations of $0.5 \mathrm{~g}$ to $2 \mathrm{~g} / 100 \mathrm{~g}$ were in the red-blue range of the CIELAB color space with a violet hue, and with higher dye concentrations were in the red-yellow range with a reddish-brown hue. They looked brown.

The prints on recycled paper (Paper 2) were in the green-yellow range and only at the highest dye concentration in the red-yellow range. They had a greenish-yellow hue as the recycled paper itself. The prints looked grey-brown.

The Japanese knotweed papers were the darkest among all the printing materials with the highest chroma values. Because J.k. 200 contained fewer stem fibers of Japanese knotweed, its color was slightly lighter and less saturated than that of J.k. 240. The prints on Japanese knotweed papers were in the red-yellow range with a brownish-yellow hue, as was the hue of the papers themselves. The prints of higher dye concentrations on Japanese knotweed papers looked more purple-brown than on other materials.

The prints on fabrics were in the red-yellow range with an orange-brown hue. The colorimetric measurements showed a greater increase in darkness and saturation of the prints on the fabrics with an increase in dye concentration than on papers. Due to the higher absorption of the ink, darker and more saturated colors of the brown prints were obtained. 
The prints produced with the bluish-green alkaline printing ink were green. The spectrophotometric measurements showed that the prints on Paper 1, Paper 2, and polyester fabric were greener than the prints on J.k. papers and cotton fabric, which had a yellowish hue.

The prints made with the acidic printing paste ( $3 \mathrm{~g}$ dye $/ 100 \mathrm{~g})$ were slightly lighter, duller, and with lower chromatic coordinates than prints made with the initial printing paste. They had a similar lightness and hue as the prints obtained with $2 \mathrm{~g}$ of dye per $100 \mathrm{~g}$ of the initial printing paste.

\subsection{Fastness of Prints}

The results of visual assessments of the resistance of the prints on paper to dry rubbing are summarized in Table 3. The visual assessments of the resistance of the prints on textiles to rubbing, ironing, washing according to the grayscale are summarized in Table 4 . The results of the lightfastness of the prints according to the blue reference scale and $\Delta E^{*} a b$ between exposed and unexposed prints are summarized in Table 5.

Table 3. Colorfastness of prints on papers to dry rubbing.

\begin{tabular}{|c|c|c|c|c|}
\hline $\begin{array}{l}\text { Examined } \\
\text { Parameters }\end{array}$ & Paper 1 & Paper 2 & J.k. 200 & J.k. 240 \\
\hline \multicolumn{5}{|c|}{ Prints of $1 \mathrm{~g}$ dye $/ 100 \mathrm{~g}$} \\
\hline Printed surface & unchanged & unchanged & unchanged & unchanged \\
\hline $\begin{array}{l}\text { Ink transfer to } \\
\text { white paper }\end{array}$ & no & no & no & no \\
\hline \multicolumn{5}{|c|}{ Prints of $3 \mathrm{~g}$ dye $/ 100 \mathrm{~g}$} \\
\hline Printed surface & unchanged & unchanged & unchanged & $\begin{array}{l}\text { slight transfer of } \\
\text { white paper to } \\
\text { the printed } \\
\text { surface }\end{array}$ \\
\hline $\begin{array}{l}\text { Ink transfer to } \\
\text { white paper }\end{array}$ & no & no & no & 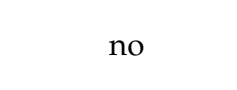 \\
\hline \multicolumn{5}{|c|}{ Prints of $3 \mathrm{~g}$ dye $/ 100 \mathrm{~g}$ (alkaline) } \\
\hline Printed surface & unchanged & unchanged & unchanged & $\begin{array}{l}\text { slight transfer of } \\
\text { white paper to } \\
\text { the printed } \\
\text { surface }\end{array}$ \\
\hline $\begin{array}{l}\text { Ink transfer to } \\
\text { white paper }\end{array}$ & no & no & no & no \\
\hline \multicolumn{5}{|c|}{ Prints of $3 \mathrm{~g}$ dye $/ 100 \mathrm{~g}$ (acidic) } \\
\hline Printed surface & unchanged & unchanged & unchanged & unchanged \\
\hline $\begin{array}{c}\text { Ink transfer to } \\
\text { white paper }\end{array}$ & no & no & no & no \\
\hline \multicolumn{5}{|c|}{ Prints of $5 \mathrm{~g}$ dye $/ 100 \mathrm{~g}$} \\
\hline Printed surface & unchanged & unchanged & unchanged & $\begin{array}{l}\text { slight transfer of } \\
\text { white paper to } \\
\text { the printed } \\
\text { surface }\end{array}$ \\
\hline $\begin{array}{l}\text { Ink transfer to } \\
\text { white paper }\end{array}$ & no & no & no & no \\
\hline
\end{tabular}


Table 4. Colorfastness of prints on fabrics to dry and wet rubbing, wet hot pressing, laundering at $40^{\circ} \mathrm{C}$.

\begin{tabular}{|c|c|c|c|c|c|c|c|}
\hline \multirow[b]{2}{*}{ Fabrics } & \multicolumn{2}{|c|}{ Rubbing } & \multicolumn{3}{|c|}{ Hot Pressing } & \multicolumn{2}{|c|}{ Washing } \\
\hline & $\begin{array}{c}\text { Staining } \\
\text { of Dry } \\
\text { Cloth }\end{array}$ & $\begin{array}{c}\text { Staining } \\
\text { of Wet } \\
\text { Cloth }\end{array}$ & $\begin{array}{c}\text { Staining } \\
\text { of Wet } \\
\text { Cloth }\end{array}$ & $\begin{array}{c}\text { Staining } \\
\text { of Dry } \\
\text { Cloth }\end{array}$ & $\begin{array}{c}\text { Color } \\
\text { Change }\end{array}$ & $\begin{array}{l}\text { Staining } \\
\text { of Cloth }\end{array}$ & $\begin{array}{l}\text { Color } \\
\text { Change }\end{array}$ \\
\hline \multicolumn{8}{|c|}{ Prints of $1 \mathrm{~g}$ dye $/ 100 \mathrm{~g}$} \\
\hline $\mathrm{CO}$ & 5 & 5 & 5 & 5 & 5 & 5 & 4 \\
\hline PES & 5 & 5 & 5 & 5 & 5 & 5 & $3-4$ \\
\hline \multicolumn{8}{|c|}{ Prints of $3 \mathrm{~g}$ dye $/ 100 \mathrm{~g}$} \\
\hline $\mathrm{CO}$ & 5 & 5 & $4-5$ & $4-5$ & 4 & 5 & 3 \\
\hline PES & 5 & 5 & $4-5$ & $4-5$ & 4 & 5 & $2-3$ \\
\hline \multicolumn{8}{|c|}{ Prints of $3 \mathrm{~g}$ dye $/ 100 \mathrm{~g}$ (alkaline) } \\
\hline $\mathrm{CO}$ & 5 & $4-5$ & $4-5$ & 5 & 4 & 5 & $2-3$ \\
\hline PES & 5 & 4 & 4 & $3-4$ & 3 & 5 & 1 \\
\hline \multicolumn{8}{|c|}{ Prints of $3 \mathrm{~g}$ dye $/ 100 \mathrm{~g}$ (acidic) } \\
\hline $\mathrm{CO}$ & 5 & 5 & $4-5$ & 5 & 4 & 5 & 2 \\
\hline PES & 5 & 5 & 4 & $3-4$ & 3 & 5 & $1-2$ \\
\hline \multicolumn{8}{|c|}{ Prints of $5 \mathrm{~g}$ dye $/ 100 \mathrm{~g}$} \\
\hline $\mathrm{CO}$ & 5 & 5 & 4 & $4-5$ & 4 & 5 & $2-3$ \\
\hline PES & 5 & $4-5$ & $3-4$ & 4 & $3-4$ & 5 & $2-3$ \\
\hline
\end{tabular}

Table 5. Colorfastness of prints to light.

\begin{tabular}{|c|c|c|c|c|c|c|}
\hline $\begin{array}{l}\text { Evaluated } \\
\text { Parameters }\end{array}$ & Paper 1 & Paper 2 & J.k. 200 & J.k. 240 & $\mathrm{CO}$ & PES \\
\hline \multicolumn{7}{|c|}{ Prints of $0.5 \mathrm{~g}$ dye $/ 100 \mathrm{~g}$} \\
\hline $\begin{array}{l}\text { Blue scale } \\
\text { assessment }\end{array}$ & 2 & 3 & 4 & 4 & 5 & 4 \\
\hline$\Delta E_{a b}^{*}$ & 15.71 & 5.96 & 3.22 & 3.26 & 2.79 & 4.79 \\
\hline \multicolumn{7}{|c|}{ Prints of $1 \mathrm{~g}$ dye $/ 100 \mathrm{~g}$} \\
\hline $\begin{array}{l}\text { Blue scale } \\
\text { assessment }\end{array}$ & $2-3$ & $3-4$ & 4 & $3-4$ & 5 & 3 \\
\hline$\Delta E_{a b}^{*}$ & 12.43 & 5.97 & 2.97 & 5.28 & 4.95 & 10.65 \\
\hline \multicolumn{7}{|c|}{ Prints of $2 \mathrm{~g}$ dye $/ 100 \mathrm{~g}$} \\
\hline $\begin{array}{l}\text { Blue scale } \\
\text { assessment }\end{array}$ & $2-3$ & 4 & 4 & 4 & 3 & 3 \\
\hline$\Delta E_{a b}^{*}$ & 12.06 & 5.32 & 5.96 & 6.16 & 9.51 & 12.46 \\
\hline \multicolumn{7}{|c|}{ Prints of $3 \mathrm{~g}$ dye $/ 100 \mathrm{~g}$} \\
\hline $\begin{array}{l}\text { Blue scale } \\
\text { assessment }\end{array}$ & 2 & $3-4$ & 3 & 2 & 3 & 2 \\
\hline$\Delta E_{a b}^{*}$ & 15.10 & 8.30 & 8.65 & 9.96 & 13.34 & 16.29 \\
\hline \multicolumn{7}{|c|}{ Prints of $4 \mathrm{~g}$ dye $/ 100 \mathrm{~g}$} \\
\hline $\begin{array}{l}\text { Blue scale } \\
\text { assessment }\end{array}$ & 2 & 4 & 2 & 2 & 3 & 2 \\
\hline$\Delta E_{a b}^{*}$ & 15.15 & 5.80 & 10.10 & 9.07 & 12.30 & 16.40 \\
\hline
\end{tabular}


Table 5. Cont.

\begin{tabular}{|c|c|c|c|c|c|c|}
\hline $\begin{array}{l}\text { Evaluated } \\
\text { Parameters }\end{array}$ & Paper 1 & Paper 2 & J.k. 200 & J.k. 240 & $\mathrm{CO}$ & PES \\
\hline \multicolumn{7}{|c|}{ Prints of $5 \mathrm{~g}$ dye $/ 100 \mathrm{~g}$} \\
\hline $\begin{array}{l}\text { Blue scale } \\
\text { assessment }\end{array}$ & 2 & 4 & 2 & 2 & 4 & 3 \\
\hline$\Delta E_{a b}^{*}$ & 15.22 & 6.10 & 11.79 & 11.10 & 12.69 & 16.82 \\
\hline \multicolumn{7}{|c|}{ Prints of $3 \mathrm{~g}$ dye /100 g (alkaline) } \\
\hline $\begin{array}{l}\text { Blue scale } \\
\text { assessment }\end{array}$ & 3 & 4 & 4 & 3 & 3 & 2 \\
\hline$\Delta E_{a b}^{*}$ & 8.85 & 8.32 & 8.52 & 9.50 & 10.28 & 16.01 \\
\hline \multicolumn{7}{|c|}{ Prints of $3 \mathrm{~g}$ dye $/ 100 \mathrm{~g}$ (acidic) } \\
\hline $\begin{array}{l}\text { Blue scale } \\
\text { assessment }\end{array}$ & 3 & 4 & 4 & 4 & 3 & 3 \\
\hline$\Delta E_{a b}^{*}$ & 8.62 & 7.83 & 8.01 & 8.90 & 13.01 & 15.21 \\
\hline
\end{tabular}

The prints on papers made with the initial ( $\mathrm{pH} 7.43$ ), alkaline ( $\mathrm{pH} 8.99)$, and acidic (pH 5.38) printing pastes exhibited good abrasion resistance when rubbed 500 times under a high pressure of $2 \mathrm{~kg}$ (Table 3). There was no ink transfer from the printing surface to the white paper. The test method of dry rubbing on papers according to ASTM D 5264, which simulates the effects of storage, shipment, and handling of printed products, was carried out under more severe conditions than on fabrics according to ISO 105-X12, where only 10 rubs under a pressure of $1 \mathrm{~kg}$ were used. The printing inks made from Impatiens glandulifera Royle extract were found to have excellent resistance to dry rubbing and can be used for printing on packaging or other paper products that are constantly rubbed with other papers.

The prints on fabrics also had excellent fastness to dry and wet rubbing (grade 5) with no color transfer, except at the highest dye concentration on polyester fabric, where slight staining of the wet cloth was seen (grade $4-5$, in Table 4). The good resistance of prints to rubbing is the result of the good strength of the bond between the polymeric binder film and the fibers for adhesion [38], which was well observed on cellulose fibers; in the case of cotton fabric and papers.

The prints on fabrics had good fastness to wet ironing; the average grade was 4, except for the highest dye concentration on polyester fabric, where the average grade was 3-4 (Table 4). The results showed weaker adhesion of the binder film to hydrophobic polyester fibers, which was expected due to the lack of available polar groups on polyester for stronger bonding [25].

The fastness of the prints on fabrics to a single commercial or domestic laundering at $40{ }^{\circ} \mathrm{C}$ was fair; slightly better on cotton, where the grade of color loss was 3 , however, the color changed from brown to green. The loss of color on polyester was slightly higher, the grade was 2-3 (Table 4), indicating not-so-stable cross-links of the binder to hydrolysis during washing and weaker interactions of the binder film with polyester fibers [25]. There was no staining of the white adjacent fabric in the washing bath, which is due to a low substantivity of the washed natural dye to the fibers.

The prints made with alkaline paste on cotton and polyester had excellent fastness to dry rubbing, but lower fastness to wet rubbing for half a grade on cotton and one grade on polyester, compared to the initial paste (Table 4). The prints on polyester with alkaline and acidic printing pastes had lower fastness to wet ironing for one grade (grade 3-4). Alkali and acid in the printing paste also impaired the colorfastness to washing. The alkali reduced the wash fastness on cotton for half a grade and polyester for one and a half grade. The acid reduced the wash fastness on both fabrics for one grade compared to the initial printing paste. 
The poorer resistance of alkaline and acidic inks to wet treatments indicates weaker adhesion of the polymeric binder with the fibers. A non-optimal pH (lower or higher than 7.5-8) of the printing paste results in the polyacrylate thickener not being present in the appropriate form of carboxylates $\left(-\mathrm{COO}^{-}\right)$[25] or at least not in a sufficiently large amount, which is why it cannot convert into the appropriate amount of polyacrylic acid during thermal fixation to accelerate the cross-linking of the binder and its interaction with the fibers.

The prints on papers and fabrics faded significantly when exposed to light, becoming lighter and yellower (Table 5). It has already been reported that light exposure of anthocyanin pigments accelerates their destruction [39]. A large color difference between exposed and unexposed prints was observed at higher dye concentrations. The average grade of fading according to the blue reference scale was 2 for prints on Papers 1,3 on the Japanese knotweed papers and polyester fabric, 4 on Paper 2, and cotton fabric, indicating poor to fair lightfastness of the printing ink [40].

The alkaline and acidic printing pastes increased the light fastness of the prints on papers for one grade compared to the neutral printing paste. The alkaline or acidic printing pastes, which improved lightfastness on paper, had no visual effect on the lightfastness of the prints on cotton fabrics; though spectrophotometric measurements showed slightly improved lightfastness of the prints. On polyester fabric, the acidic paste increased the light fastness of the prints for one grade.

The addition of acetic acid or soda ash in the prints could neutralize the destructive effect of UV light on the dye molecules, which has already been demonstrated for ascorbic acid and gallic acid [41,42], which have been effectively used to improve the lightfastness of cotton dyed with natural dyes in the post-treatment process. However, the effects of acid and alkali on the lightfastness properties of the prints need further investigation.

\section{Conclusions}

A violet dye extracted from the purple-pink petals of the invasive alien plant Impatiens glandulifera Royle can be used as a natural dye with a pigment printing paste to produce screen printing inks up to a concentration of $5 \mathrm{~g}$ of the dye per $100 \mathrm{~g}$ of printing paste. Higher concentrations of the dye extract impaired the performance of the acrylate-based thickener and consequently lowered the viscosity of the printing ink.

The prints were purple-brown on Japanese knotweed papers and browner on other substrates. Greater absorption of the inks and darker colors were obtained on the fabrics. All prints had very good rubbing fastness, but faded considerably when exposed to light (average grade 3). The wash fastness of the prints on cotton fabric was fair (grade 3) and poor on polyester fabric (grade 2-3), but the prints had good resistance to wet ironing (grade 4).

The addition of acid to the printing paste caused a lighter violet color and the addition of alkali drastically changed the color of the ink to green. Both additives increased the light fastness of the prints, especially on papers for one grade; however, they decreased the wet fastness of the prints on fabrics, on average for one grade.

Due to the excellent adhesion resistance of the printing ink to extreme numbers of rubbing repetitions, the natural dye can be successfully used for printing on paper products that are not directly exposed to light. However, its use on textiles is limited due to its lower wash fastness.

Funding: This research was funded by the European research project UIA02-228 APPLAUSE.

Institutional Review Board Statement: Not applicable.

Informed Consent Statement: Not applicable.

Data Availability Statement: Not applicable. 
Acknowledgments: The author thanks the project partners; the National Institute of Chemistry (Ljubljana, Slovenia) for the preparation of dye extract and Pulp and Paper Institute (Ljubljana, Slovenia) for the production of Japanese knotweed papers.

Conflicts of Interest: The author declares no conflict of interest. The funder had no role in the design of the study; in the collection, analyses, or interpretation of data; in the writing of the manuscript, or in the decision to publish the results.

\section{References}

1. Hebeish, A.; Shahin, A.A.; Rekaby, M.; Ragheb, A.A. New environment-friendly approach for textile printing using natural dye loaded chitosan nanoparticles. Egypt. J. Chem. 2015, 58, 659-670.

2. Rungruangkitkrai, N.; Mongkholrattanasit, R. Eco-Friendly of Textiles Dyeing and Printing with Natural Dyes. In Proceedings of the International Conference: Textiles \& Fashion 2012, Bangkok, Thailand, 3-4 July 2012; pp. 1-16.

3. Devi, S.; Karuppan, P. Reddish brown pigments from Alternaria alternata for textile dyeing and printing. Indian J. Fibre Text. Res. 2015, 40, 315-319.

4. Rekaby, M.; Salem, A.A.; Nassar, S.H. Eco-friendly printing of natural fabrics using natural dyes from alkanet and rhubarb. J. Text. Inst. 2009, 100, 486-495. [CrossRef]

5. Salem, A.A.; Shahin, M.F.; El Sayad, H.S.; El Halwagy, A.A. Transfer printing of polyester fabrics with natural dyes. Res. J. Text. Appar. 2013, 17, 61-67. [CrossRef]

6. Chattopadhyay, S.N.; Pan, N.C.; Khan, A. Printing of jute fabric with natural dyes extracted from manjistha, annatto and ratanjot. Indian J. Fibre Text. Res. 2018, 43, 352-356.

7. Osman, H. Eco-friendly printing of textile substrates with rhubarb natural dye nanoparticles. World Appl. Sci. J. 2014, 29, 592-599. [CrossRef]

8. Teli, M.D.; Sheikh, J.; Shastrakar, P. Exploratory investigation of chitosan as mordant for eco-friendly antibacterial printing of cotton with natural dyes. J. Text. 2013, 2013, 320510. [CrossRef]

9. Pratoomtong, T. The property of screen ink from natural mordant, colorant, and additive for art. IJBSS 2015, 6, 68-76.

10. Ragheb, A.A.; Tawfik, S.; Abd-El Thalouth, J.I.; Mosaad, M.M. Development of printing natural fabrics with curcuma natural dye via nanotechnology. IJPSR 2017, 8, 611-620. [CrossRef]

11. Abd-El-Thalouth, J.I. Synthesis and application of eco-friendly natural-printing paste for textile coloration. J. Am. Sci. 2011, 7, 632-640. [CrossRef]

12. Bahtyari, M.I.; Benli, H.; Yavas, A. Printing of wool and cotton fabrics with natural dyes. Asian J. Chem. 2013, $25,3220-3224$. [CrossRef]

13. Babel, S.; Gupta, R. Screen printing on silk fabric using natural dye and natural thickening agent. J. Text. Sci. Eng. 2016, 6, 1000230. [CrossRef]

14. Savvidis, G.; Karanikas, E.; Nikolaidis, N.; Eleftheriadis, I.; Tsatsaroni, E. Ink-jet printing of cotton with natural dyes. Color Technol. 2013, 130, 200-204. [CrossRef]

15. Bahtyari, M.I.; Benli, H.; Yavas, A.; Akça, A.C. Use of different natural dye sources for printing of cotton fabrics. Text. Appar. 2017, 27, 259-265.

16. Savvidis, G.; Zarkogianni, M.; Karanikas, E.; Lazaridis, N.; Nikolaidis, N.; Tsatsaroni, E. Digital and conventional printing and dyeing with the natural dye annatto: Optimization and standardization process to meet future demands. Color. Technol. 2012, 129, 55-63. [CrossRef]

17. Cafa, G.; Baroncelli, R.; Ellison, C.A.; Kurose, D. Impatiens glandulifera (Himalayan balsam) chloroplast genome sequence as a promising target for populations studies. PeerJ 2020, 8, e8739. [CrossRef] [PubMed]

18. Karlovits, I.; Kavčič, U.; Lavrič, G.; Šinkovec, A.; Torić, V. Digital printability of papers made from invasive plants and agroindustrial residues. Cellul. Chem. Technol. 2020, 54, 523-529. [CrossRef]

19. Horvat, M.; Iskra, J.; Pavlič, M.; Žigon, J.; Merela, M. Wood dyes from invasive alien plants. Les Wood 2020, 69, 37-48. [CrossRef]

20. Gorjanc, M.; Savić, A.; Topalić-Trivunović, L.; Mozetič, M.; Zaplotnik, R.; Vesel, A.; Grujić, D. Dyeing of plasma treated cotton and bamboo rayon with Fallopia Japonica extract. Cellulose 2016, 23, 2221-2228. [CrossRef]

21. Gorjanc, M.; Kert, M.; Mujadžić, A.; Simončič, B.; Forte-Tavčer, P.; Tomšič, B.; Kostanjšek, K. Cationic pretreatment of cotton and dyeing with Fallopia Japonica leaves. Tekstilec 2019, 62, 181-186. [CrossRef]

22. Topič, T.; Gorjanc, M.; Kert, M. The influence of the treatment process on the dyeability of cotton fabric using goldenrod dye. Tekstilec 2018, 61, 192-200. [CrossRef]

23. Klančnik, M. Screen printing with natural dye extract from Japanese knotweed rhizome. Fiber Polym. 2021, in press.

24. Viera, M.N.; Winterhalter, P.; Jerz, G. Flavonoids from the flowers of Impatiens glandulifera Royle isolated by high performance countercurrent chromatography. Photochem. Anal. 2016, 27, 116-125. [CrossRef]

25. Broadbent, A.D. Printing. In Basic Principles of Textile Coloration; Society of Dyers and Colourists: Bradford, UK, 2001; pp. 509-526.

26. ASTM. Standard Practice for Abrasion Resistance of Printed Materials by the Sutherland Rub Tester; ASTM D 5264-98; ASTM International: West Conshohocken, PA, USA, 2019.

27. ISO. Textiles_-Tests for Colour Fastness_Part X12: Colour Fastness to Rubbing; ISO 105-X12; ISO: Geneva, Switzerland, 2016.

28. ISO. Textiles_-Tests for Colour Fastness_Part X11: Colour Fastness to Hot Pressing; ISO 105-X11; ISO: Geneva, Switzerland, 1994. 
29. ISO. Textiles_-Tests for Colour Fastness_-Part C06: Colour Fastness to Domestic and Commercial Laundering; ISO 105-C06; ISO: Geneva, Switzerland, 2012.

30. ISO. Textiles-Tests for Colour Fastness_Part A02: Grey Scale for Assessing Change in Colour; ISO 105-A02; ISO: Geneva, Switzerland, 1993.

31. ISO. Textiles-Tests for Colour Fastness_Part A03: Grey Scale for Assessing Staining; ISO 105-A03; ISO: Geneva, Switzerland, 2019.

32. ISO. Textiles-Tests for Colour Fastness_-Part B02: Colour Fastness to Artificial Light: Xenon Arc Fading Lamp Test; ISO 105-B02; ISO: Geneva, Switzerland, 2014.

33. Broadbent, A.D. Colour measurement. In Basic Principles of Textile Coloration; Society of Dyers and Colourists: Bradford, UK, 2001; pp. 465-468.

34. Khoo, H.E.; Azlan, A.; Tang, S.T.; Lim, S.M. Anthocyanidins and anthocyanins: Colored pigments as food, pharmaceutical ingredients, and the potential health benefits. Food Nutr. Res. 2017, 61, 1361779. [CrossRef]

35. Rose, P.M.; Cantrill, V.; Benohoud, M.; Tidder, A.; Rayner, C.M.; Blackburn, R.S. Application of anthocyanins from blackcurrant (Ribes nigrum L.) fruit waste as renewable hair dyes. J. Agric. Food Chem. 2018, 66, 6790-6798. [CrossRef] [PubMed]

36. Szewczyk, K.; Cicek, S.S.; Zidorn, C.; Granica, S. Phenolic constituents of the aerial parts of Impatiens glandulifera Royle (Balsaminaceae) and their antioxidant activities. Nat. Prod. Res. 2019, 33, 2851-2855. [CrossRef] [PubMed]

37. Szewczyk, K.; Kalemba, D.; Komsta, L.; Nowak, R. Comparison of essential oil composition of selected Impatiens species and its antioxidant activities. Molecules 2016, 21, 1162. [CrossRef] [PubMed]

38. Yaman, N.; Ozdogan, E.; Seventekin, N. Improvement Fastnesses and Color Strength of Pigment Printed Textile Fabric. J. Eng. Fibers Fabr. 2012, 7, 40-46. [CrossRef]

39. Amogne, N.Y.; Ayele, D.W.; Tsigie, Y.A. Recent advances in anthocyanin dyes extracted from plants for dye sensitized solar cell. Mater. Renew. Sustain. Energy 2020, 9, 23. [CrossRef]

40. Broadbent, A.D. Testing of dyes and dyeings. In Basic Principles of Textile Coloration; Society of Dyers and Colourists: Bradford, UK, 2001; pp. 527-540.

41. Criesta, D.; Vilarem, G. Improving light fastness of natural dyes on cotton yarn. Dyes Pigment. 2006, 70, 238-245. [CrossRef]

42. Thiagarajan, P.; Nalankilli, G. Improving light fastness of reactive dyed cotton fabric with antioxidant and UV absorbers. Indian J. Fibre Text. Res. 2013, 38, 161-164. 